DOI: 10.34015/2523-4552.2021.2.14

УДК 159.9

Ліненко О. I., аспірант Академії праці, соціальних відносин і туризму ORCID: 0000-0001-9090-1926

\title{
ПРОБЛЕМНІ ПИТАННЯ ПРАВОВОГО РЕГУЛЮВАННЯ ПСИХОЛОГІЧНОЇ РЕАБІЛІТАЦІЇ ВІЙСЬКОВОСЛУЖБОВЦІВ ТА УЧАСНИКІВ БОЙОВИХ ДІЙ
}

Незважаючи на наявність в українському законодавстві низки нормативно-правових документів, які регулюють питання здійснення реабілітації військовослужбовців, що отримали поранення або психологічні травми під час бойових дій, чинне законодавство України на сьогодні не в змозі у повному обсязі забезпечити проведення належного рівня комплексної реабілітації таких військовослужбовців. Даний науковий матеріал розкриває низку проблемних питань 3 цього напряму, які існують в чинному законодавстві України та пропонує власне бачення вирішення нагальних потреб та неузгодженостей в адміністративно-правовому полі.

Ключові слова: військовослужбовець; учасник бойових дій; учасник антитерористичної операції; психічна травма; психологічна реабілітація; бойові психічні травми; заходи превентивної реабілітації та психокорекції.

Несмотря на наличие в украинском законодательстве ряда нормативноправовых документов, регулирующих вопросы осуществления реабилитации военнослужащих, получивших ранения или психологические травмы во время боевых действий, действующее законодательство Украины на сегодня не в состоянии в полном объеме обеспечить проведение надлежащего уровня комплексной реабилитации таких военнослужащих. Данный научный материал раскрывает ряд проблемных вопросов в этом направлении, которые существуют в действующем законодательстве Украины и предлагает свое видение решения насущных проблем и неувязок в административноправовом поле.

Ключевые слова: военнослужащий; участник боевых действий; участник антитеррористической операции; психическая травма; психологическая реабилитация; боевые психические травмы; меры превентивной реабилитации и психокоррекции.

Постановка проблеми. Незалежно від статусу або військового звання кожен військовослужбовець у процесі своєї діяльності підпадає під різноманітні стресові фактори, які у подальшому стають причиною низки психічних станів (напруження, психічні травми, постттравматичний розлад, втома, виснаження, невроз тощо), кожен з яких має індивідуальні симптоми, форми прояву i наслідки. 
Сьомий рік поспіль на Сході України йде війна, кількість військовослужбовців які брали участь у бойових діях постійно росте. На сьогоднішній день понад 350 тисяч українців отримали статус учасника бойових дій. Понад $75 \%$ таких осіб потребують психологічної реабілітації, а 32\% - необхідних тривалих реабілітаційних заходів.

Лише за перших чотири з половиною років війни, в Україні зафіксовано понад тисячу суїцидів серед військовослужбовців даної категорії, більше половини (66\%) з яких відбулася не на лінії зіткнення з безпосереднім противником, а в пунктах постійної дислокації військовослужбовців. Причиною цьому $є$ те, що багато учасників бойових дій не $\epsilon$ професійними військовими, не проходили курс психологічної підготовки і просто не знають як впоратися зі стресом, який виник під час їх участі в бойових діях [1, с. $4 ; 2$, с. $36 ; 3$, с. 85].

Питання психологічної реабілітації учасників бойових дій $\epsilon$ дуже актуальним в нашій державі, оскільки розроблений, на сьогоднішній день комплекс адміністративно-правових заходів їх реабілітації має частковий і безсистемний характер, i не завжди призводить до покращення позитивної динаміки у них.

Основними завданнями психологічної реабілітації учасників бойових дій є: виявлення та діагностика у них психічних розладів, сортування таких військовослужбовців за рівнем психо-травматизації, їх відсторонення від участі в бойових діях та відновлення у них порушених (втрачених) психічних функцій, корекція їхньої самосвідомості, самооцінки і самопочуття, попередження розвит- ку хронічних і відстрочених форм стресу, формування у них ефективних моделей поведінки в різних ситуаціях, навичок саморегуляції психічних станів, швидке повернення до бойового строю.

На наш погляд, порядок вирішення зазначених завдань не в повній мірі регламентовано на законодавчому рівні, що призводить до неналежного забезпечення проведення комплексної реабілітації військовослужбовців, які приймали участь в бойових діях.

Постановка завдання. Розкрити низку проблемних питань щодо порядку реабілітації військовослужбовців, які приймали участь в бойових діях та знайти власне бачення вирішення нагальних потреб та неузгодженостей в адміністративно-правовому полі 3 цього питання.

Виклад основного матеріалу. Участь у бойових діях для людини ніколи не проходить безслідно. В бою, під дією стресових факторів у людини формується нова модель поведінки, яка допомагає вижити у зоні конфлікту, де автоматично змінюється протікання психічних процесів, які формувалися в повсякденному житті.

В умовах бойових дій, будь-яка особа зазнає значних зовнішніх та внутрішніх впливів, що в свою чергу призводять до елементарної стомленості та зниження ефективності бойової діяльності. Саме втома, яка на перший погляд являється не значною в організмі людини, негативно впливає на всі психічні та психофізіологічні процеси, бо саме через втому знижується увага, порушується пам'ять, мислення, можуть виникати ілюзї̈, конфліктні ситуації 3 
товаришами по службі, тощо. Коли стомленість організму не компенсується відпочинком, вона має схильність акумулюватися і досягати критичних рівнів.

Під час своїх досліджень німецький вчений Е. Дінтер встановив, що перебування особового складу безпосередньо на передньому краї більше ніж 30-40 діб стає непродуктивним. Це пов'язано з тим, що після досягнення максимуму моральнопсихічних можливостей, який наступає через 20-25 діб, у військовослужбовців настає швидкий спад, обумовлений виснаженням духовних i фізичних сил [4, с. 38].

Під час бойових дій військовослужбовці досить часто отримують психічні травми (їх ще називають психічні розлади), які викликають часткову або повну втрату бойової готовності воїна в екстремальних умовах бойових дій та після їх закінчення.

Виникненню

бойових психічних травм сприяють:

а) психічні перевантаження військовослужбовців у бойовій обстановці: постійна реальна загроза життю; система жорсткої відповідальності за належне виконання бойового завдання; недостатність і невизначеність інформації, що надходить; дефіцит часу під час ухвалення рішення; невідповідність рівня військово-професійної підготовки військовослужбовця реальним умовам бойової обстановки, його психічна неготовність до дій у бойових умовах; кумулятивний, індуційований варіант перебігу реакцій у групах людей, наприклад, миттєве поширення паніки серед воїнів; повна або часткова ізоляція воїнів від основних сил тощо; б) бойові фізіологічні перевантаження: фізичне виснаження в результаті перенапруження та порушення режиму харчування; порушення режиму сну;

в) умови бойової діяльності: виконання розпорядку дня і дисциплінарних вимог; організація побуту, забезпечення потреб і запитів воїнів; незвичні умови служби та бойових дій (клімат, погода, місцевість тощо); переживання особистого характеру (хвороба і смерть близьких, службові негаразди, фінансові проблеми тощо) [5, с. 280].

Кожен напевно чув такий термін як «В'єтнамський синдром», але мало хто замислювався, чому наші предки після більш серйозних війн, таких як наприклад, Велика Вітчизняна Війна, не страждали ніякими психічними розладами, пов'язаними з участю в бойових діях. Це можна пояснити наступним. Війна у В'єтнамі - один 3 найбільших військових конфліктів другої половини XX століття. Даний конфлікт можна розділити на кілька періодів: партизанська війна в Південному В'єтнамі (1957 - березень 1965 рр.), повномасштабне військове втручання США (березень 1965-1973) і завершальний етап війни (19731975 pp.) [6].

В'єтнамська війна починалася i планувалася як звичайна військова короткострокова спецоперація. Однак, вона переросла в затяжний конфлікт, з великими втратами і вбивствами величезної кількості мирного населення. Майже одразу, американські солдати перестали відчувати себе визволителями і перетворилися в усвідомлених вбивць і садистів, особливо коли американська армія почала активно застосовувати 
напалм, яким заживо спалювали цілі села 3 мирними жителями. Все це відбувалося на очах американських солдатів і офіцерів, що негативно позначилося на їхній психіці.

Через В'єтнамський конфлікт, пройшли 2,5 мільйона американців, більшість 3 яких були молодими хлопцями. Втрати вбитими склали більше 58 тисяч солдатів і офіцерів. Понад 150 тисяч ветеранів В'єтнаму вже перебуваючи у себе на Батьківщині, покінчили життя самогубством, не витримавши спогадів про участь в бойових діях. Американська влада намагалися приховувати цю статистику, видаючи суїцид за нещасні випадки, але все було марно [7].

Як не дивно, але «В'єтнамським синдромом» страждають і українські військовослужбовці, які пройшли локальну фазу конфлікту на Сході України. В одному зі своїх інтерв'ю, військовий прокурор А. Матіос розповів, що суїцид став великою проблемою для української армії. Так, у 2018 році було зафіксовано більше 800 випадків самогубств українських військовослужбовців [8] Науковцями вже давно помічено, що, самогубство має свої статеві та вікові особливості. Рівень суїцидів серед чоловічої статі завжди є вищим, аніж серед жіночої. Співвідношення чоловіків і жінок, які зводять рахунки з життям, становить 4:1 [9, с. 912].

Сьогодні в українську армію призивають молодих людей у віці від 20 років. Це соціальний вік, який у плані соціального та професійного становлення вважається надзвичайно складним і відповідальним для особистості. Але, підвищена вимогливість, часто не нормований робочий графік, регулярні фізичні, мо- ральні та психологічні навантаження в армійському середовищі провокують появу у них стресових станів, підвищену тривожність, депресію, а відтак і спроби суїциду. Не дивлячись на визначені проблеми морально-психологічного забезпечення військ, у 46-й статті Конституції України закріплено право кожного громадянина на соціальний захист 3 боку держави. Тому створення та гарантування належних умов для достойного життєвого рівня громадян, на сьогоднішній день є пріоритетним завданням для української держави [10].

Таким чином, психологічна підготовка і реабілітація для кожного військовослужбовця, являється невід'ємною складовою гарантій соціального забезпечення. Одним із пріоритетних напрямків для нашої держави повинно стати адміністративно-правове регулювання на законодавчому рівні процесів психологічної та фізичної реабілітації військовослужбовців які брали участь у бойових діях.

У Законі України «Про соціальний і правовий захист військовослужбовців та членів їх сімей» вказані основні пріоритетні напрямки державної політики, які безпосередньо стосуються соціального захисту військовослужбовців та членів їх сімей [11].

На початку кризових явищ 2014 року, Національна гвардія України стала військовим формуванням підрозділи якої одними 3 перших почали виконувати службовобойові завдання щодо захисту територіальної цілісності, збереження конституційного ладу та захисту прав, свобод і законних інтересів громадян в районах Донецької та 
Луганської областей. Першим підзаконним актом який мав вирішити проблемні питання реабілітації учасників бойових дій, став Наказ командувача Національної гвардії України від 25.09.2014 № 303 «Про вдосконалення організації моральнопсихологічного забезпечення участі військових частин (підрозділів) Національної гвардії України в проведенні заходів антитерористичної операції» [12].

Пізніше, $з$ метою вирішення нагальних питань у напрямку реабілітації, була затверджена низка державних нормативно-правових актів, а саме: Указ Президента України від 18 березня 2015 №150/2015 «Про додаткові заходи щодо соціального захисту учасників антитерористичної операції» [13] та Розпорядження КМУ від 31 березня 2015 № 359-р «Про затвердження плану заходів щодо медичної, психологічної, професійної реабілітації та соціальної адаптації учасників антитерористичної операції» [14]. На основі цих документів, було затверджено низку відомчих підзаконних актів щодо організації психологічної реабілітації учасників бойових дій, а саме: Наказ Міністерства соціальної політики України від 23.06.2015 № 650 «Про затвердження Положення про міжвідомчу комісію з питань організації психологічної реабілітації постраждалих учасників антитерористичної операції» [15] та відповідно до підпункту 30 пункту 4 Положення про МВС України, затвердженого постановою Кабінетів Міністрів України від 28 жовтня 2015 року № 878, з напрямком організації системи психологічного забезпечення в Національній гвардії України було затверджено «Поло- ження про психологічне забезпечення в Національній гвардії України» [16].

Разом із тим, спеціалізованими органами Міністерства Оборони України були розроблені та затверджені нормативно-правові акти які ставили за мету вирішення питань медико-психологічної реабілітації, а саме:

Наказ МО України від 09.12.2015 № 702 «Про затвердження Положення про психологічну реабілітацію військовослужбовців Збройних Сил України, які брали участь в антитерористичній операції, під час відновлення боєздатності військових частин (підрозділів)» [17];

Наказ МО України від 09.12.2015 № 703 «Про затвердження переліків медичних показань та протипоказань до санаторного лікування і медичної реабілітації в санаторно-курортних закладах Збройних Сил України» [18];

Накази МО України від 04.11.2016 № 591 та від 17.07.2018 № 337 «Про затвердження Інструкції про організацію санаторнокурортного лікування, медичної та медико-психологічної реабілітації у Збройних Силах України» [19];

Наказ МО3 України від 19.06.2015 № 351 «Про затвердження Плану заходів щодо медичної, психологічної, професійної реабілітації та соціальної адаптації учасників антитерористичної операції» [20] та Наказ МОЗ України від 23.02.2016 № 121 «Про затвердження та впровадження медикотехнологічних документів зі стандартизації медичної допомоги при посттравматичному стресовому розладі», в якому були викладені 
механізми регуляції вузьконаправлених проблемних питань і стосувалися суто посттравматичних стресових розладів, не враховуючи інших психологічних проблем учасників бойових дій [21].

Не дивлячись на низку розроблених та запроваджених нормативно-правових актів на законодавчому рівні, механізм надання психологічної реабілітації військовим не зміг запрацювати на повну потужність ізза погано сформованої матеріальної бази та не до кінця опрацьованих розбіжностей у правовому полі. У зв'язку з цим, для вирішення зазначених питань було взято за основу постанову Кабінету Міністрів України від 12 липня 2017 р. № 497 «Про затвердження Порядку використання коштів, передбачених у державному бюджеті для здійснення заходів щодо психологічної реабілітації постраждалих учасників антитерористичної операції та постраждалих учасників Революції Гідності» [22], розпорядження Кабінету Міністрів України від 12 липня 2017 р. № 475-р «Про схвалення Концепції Державної цільової програми з фізичної, медичної, психологічної реабілітації і соціальної та професійної реадаптації учасників антитерористичної операції на період до 2022 року» [23] та постанову Кабінету Міністрів України від 27 грудня 2017 р. № 1057 «Про затвердження Порядку проведення психологічної реабілітації учасників антитерористичної операції та постраждалих учасників Революції Гідності» [24]. Розпочалася робота за напрямком створення системних підходів щодо надання спеціалізованої медико-психологічної допомоги та реабілітації учасників бойових дій.
Згодом, за сприянням Міністерства соціальної політики, представників міжнародних організацій а також професійної спільноти психологів, Верховна Рада України прийняла законопроєкт №7505, яким рекомендувала створити окреме «Міністерство у справах ветеранів», одним із пріоритетних завдань якого $€$ забезпечення адаптації та психологічної реабілітації ветеранів війни. В подальшому даний законопроєкт був затверджений Постановою ВРУ від 27 лютого 2018 року № 2294-VIII «Про звернення Верховної Ради України до Кабінету Міністрів України щодо створення Міністерства України у справах ветеранів центрального органу виконавчої влади для забезпечення формування та реалізації державної політики у сфері соціального захисту ветеранів війни».

27 червня 2018 року в Міністерстві соціальної політики України відбулося підписання Меморандуму про співпрацю між Мінсоцполітики та Національною гвардією України щодо соціально-психологічної адаптації учасників бойових дій.

Разом $з$ тим, не дивлячись на зроблені кроки у даному напрямку, чисельну кількість законодавчих ініціатив, наша держава не зробила всіх необхідних заходів щоб вирішити цю проблему. Так, упродовж 2014-2020 рр. в обсязі бюджетного фінансування підрозділів НГУ, з боку державного забезпечення кошти на потреби психологічної реабілітації учасників бойових дій не виділялись. На сьогоднішній день в Україні відсутні відомчі державні цільові програми та реабілітаційні бази для реабілітації таких військовослужбовців. Психологічна служба НГУ 
спільно із колегами інших складових Сектору Безпеки Оборони брала активну участь у міжвідомчих робочих групах, спільно опрацьовувала єдину Державну цільову програму (КПКВК 1501040) та порядок їі реалізації. Однак, кінцеве рішення по цій програмі до цього часу не прийнято.

Також, Україна зіштовхнулась iз ситуацією, коли фактична реалізація заходів психологічної реабілітації учасників бойових дій продемонструвала недостатню компетентність посадових осіб органів соціального захисту населення (замовників послуг із психологічної реабілітації) та ефективність взаємодії із командирами (бригад, полків, батальйонів). Дуже часто, замовники послуг плутають психологічну реабілітацію із санаторнокурортним лікуванням, вдаються до затягування прийняття рішення (за часом), маніпуляцій з обліком звернень (не реєструючи заяви командирів у журналі, складання віртуального графіку), ігнорування запитів командирів 3 лобіюванням потреб осіб звільнених з військової служби. Як результат, командири стають заложниками ситуації та планують заходи службово-бойової діяльності, виходячи з тої ситуації, яка склалася у цивільному секторі.

Заходи превентивної реабілітації та психокорекції в місцях дислокації військових підрозділів здійснюються силами офіцерівпсихологів, позаштатними групами психологічної підтримки, високомобільними групами внутрішньої комунікації, громадськими організаціями психологів-волонтерів, 3 якими укладені відповідні меморандуми про співпрацю.
Медична та медикопсихологічна реабілітація військовослужбовців учасників АТО здійснюється у Військово-медичних клінічних центрах, госпіталях та Центрах медичної реабілітації МО України. Але, низька якість психологічної реабілітації у деяких реабілітаційних установах, відсутність механізму перевірки якості надання послуг із психологічної реабілітації потребує затвердження на законодавчому рівні єдиних типових програм, стандартів, протоколів щодо проведення психологічної реабілітації комбатантів, а також психологічного супроводу осіб, що перебували в умовах примусової ізоляції.

Висновки. У комплекті з економічними, політичними і соціальними наслідками, війна залишає слід у психологічному стані не тільки військовослужбовців а й у пересічних громадян. Особливо це стосується тих, хто бачив кров і смерть своїми очима. Військова служба зобов'язує чоловіків брати в руки зброю, захищати свою батьківщину. Вони перебувають у стані постійного очікування смерті, бачать поранення та смерть товаришів по службі. Все це залишає глибокий відбиток в їх духовному і психологічному стані. Проте далеко не всі можуть повернутися з таким станом у соціум і далі вести звичайне спокійне життя. Руйнівні наслідки бойових дій, мають безліч облич. Деякі 3 них відстрочені i пом'якшені, інші впливають на психіку людини, змінюючи світогляд, розхитуючи врівноваженість, емоційний фон і стабільність. Перебуваючи в такому стані, людина потребує кваліфікованої допомоги.

Реабілітація військовослужбовців - це шанс знайти стабільність і 
опору, відновити життєві цінності та орієнтири, щоб адаптуватися в мирному соціумі. Війну навряд чи можна назвати нормальним періодом. Посттравматичний стресовий розлад для чоловіків після військових дій - зрозуміле явище. Але сподіватися на самостійну реабілітацію не варто. Відновленню сприяє обстановка i кваліфікований склад психологів, який зможе надати професійну допомогу і повернути людину в психічно стабільний і здоровий стан.

Подальше ігнорування проблеми реабілітації військовослужбовців 3 боку держави призводить до погіршення суспільно-політичної і криміногенної обстановки в країні, та вимагає невідкладних і обов'язкових заходів для вирішення даного питання.

Реалізація фізичної, медичної, психологічної реабілітації і соціальної та професійної реадаптації учасників бойових дій потребує здійснення організаційно-правових заходів, пов'язаних із проведенням цілеспрямованих та скоординованих дій 3 боку органів державного управління, виконавчої влади, органів місцевого самоврядування, недержавних установ, громадських організацій та в загальнодержавному масштабі повинна забезпечити лікувальну, соціальну та економічну ефективність.

Існуючі законодавчі та підзаконні акти щодо реабілітації учасників бойових дій $€$ неповними та частковими. Рівень координації між уповноваженими центральними органами виконавчої влади та організаціями, що надають послуги 3 реабілітації, визнаний недостатнім. Відсутність цілісної системи реабілітаційних послуг, кадрове забезпечення по реабілітації не досягає світових та європейських стандартів. Лише побудова сучасної системи реабілітації, її затвердження на законодавчому рівні, підкріпленому бюджетними програмами, здатна забезпечити ефективне та стале вирішення проблеми.

Система надання психологічної допомоги та реабілітації учасників бойових дій за обсягом матеріальнотехнічного та кадрового забезпечення повинна розглядатись як складова національної безпеки держави.

\section{Список використаних джерел}

1. Військово-медична доктрина України (Проєкт). O.I. Затинайко, Г. В. Мясников. Новости. Медищины и фармации в Украине. 2014. № 19. С. 3-5.

2. Збереження працездатності військовослужбовців керівного складу різного віку, які працюють в умовах постійної дії стрес-чинників: метод. реком. В. В. Кальниш, Е. М. Хорошун, А. Ю. Салієв, А. В. Швець, А. Ю. Кіх. Київ, 2016. 36 с.

3. Система реабілітації військовослужбовців 3 бойовою нейротравмою в Збройних Силах України / Стеблюк В.В., Проноза-Стеблюк К.В. Med\&Psy Rehab: Maтеріали міжнародного конгресу з медичної і психологічної реабілітації (м. Київ, 30-31 жовтня 2017 р.). Київ, 2017. С. 84- 86.

4. Иванов А. Л. Психологические последствия участия военнослужащих в боевых действиях в Чеченской республике и их медикопсихолого-социальная коррекция в условиях Всеармейского реабилитационного центра. Вестник психосоциальной и коррекционно-реабилитационной работы. 2003. №4. С. 32-44.

5. Иванов А. Л., Жуматий Н. В. Психологическая реабилитация военнослужащих, получивших тяжелые ранения и увечья в Чеченской Республике методом психо- 
аналитического консультирования и психодрамы. Материалы V Всероссийской научно-практической по психотерапии и клинической психологии «Душевное здоровье человека - здоровье нации», Изд-во Института Психотерапии, 2002. 280 с.

6. Посттравматическое стрессовое расстройство URL : https://ru.wikipedia.org

7. Людские потери во Вьетнамской войне URL : https://ru.wikipedia.org

8. Інтернет-видання «Ліга-нет». Інтерв'ю А. Матіоса. URL https://news.liga.net/society/news/matios-ozvuchil-ujasayuschuyu-statistiku-neboevyhpoter-v-vsu.

9. В поисках смысла / сост. А. Е. Мачехин. Изд. 2-е, перераб. и доп. Москва : ОЛМА-ПРЕСС, 2005. 912 с.

10. Конституція України URL : https://zakon.rada.gov.ua/laws/show/ 254\%D0\%BA/96-\%D0\%B2\%D1\%80\#Text.

11. Закон України «Про соціальний і правовий захист військовослужбовців та членів їх сімей» URL : https://zakon.rada.gov.ua/laws/show/2011-12\#Text.

12. Наказ командувача Національної гвардії України від 25.09.2014 № 303 «Про вдосконалення організації морально-психологічного забезпечення участі військових частин (підрозділів) Національної гвардії України в проведенні заходів антитерористичної операції».

13. Указ Президента України від 18 березня 2015 №150/2015 «Про додаткові заходи щодо соціального захисту учасників антитерористичної операції» URL : https://zakon.rada.gov.ua/laws/show/150/2015\#Text.

14. Розпорядження КМУ від 31 березня 2015 № 359-р «Про затвердження плану заходів щодо медичної, психологічної, професійної реабілітації та соціальної адаптації учасників антитерористичної операції» URL : https://zakon.rada.gov.ua/ laws/show/359-2015-\%D1\%80\#Text.

15. Наказ Міністерства соціальної політики України від 23.06.2015 № 650 «Про затвердження Положення про міжвідомчу комісію 3 питань організації психологічної реабілітації постраждалих учасників антитерористичної операції» URL : https://zakon.rada.gov.ua/laws/show/z0803-15\#Text.

16. Постановою КМУ від 28 жовтня 2015 року № 878, «Положення про психологічне забезпечення в Національній гвардії України» URL : https://zakon.rada.gov.ua/laws/show/878-2015-\%D0\%BF\#Text.

17. Наказ МО України від 09.12.2015 № 702 «Про затвердження Положення про психологічну реабілітацію військовослужбовців Збройних Сил України, які брали участь в антитерористичній операції, під час відновлення боєздатності військових частин (підрозділів)» URL : https://www.mil.gov.ua/content/gsc_orders/ MOU2015_702.pdf.

18. Наказ МО України від 09.12.2015 № 703 «Про затвердження переліків медичних показань та протипоказань до санаторного лікування і медичної реабілітації в санаторно-курортних закладах Збройних Сил України» URL : https://zakon.rada.gov.ua/laws/show/z1681-15\#Text.

19. Наказ МО України від 04.11.2016 № 591 та від 17.07.2018 № 337 «Про затвердження Інструкції про організацію санаторнокурортного лікування, медичної та медико-психологічної реабілітації у Збройних Силах України» URL : https://zakon.rada.gov.ua/laws/show/z1538-16\#Text.

20. Наказ МОЗ України від 19.06.2015 № 351 «Про затвердження Плану заходів щодо медичної, психологічної, професійної реабілітації та соціальної адаптації учасників антитерористичної операції» URL : https://zakon.rada.gov.ua/rada/ show/v0351282-15\#Text.

21. Наказ МОЗ України від 23.02.2016 № 121 «Про затвердження та впровадження медико-технологічних документів зі стандартизації медичної допомоги 
при посттравматичному стресовому розладі» URL : http://search.ligazakon.ua/ 1_doc2.nsf/link1/MOZ25625.html.

22. Постанова КМУ від 12 липня 2017 р. № 497 «Про затвердження Порядку використання коштів, передбачених у державному бюджеті для здійснення заходів із психологічної реабілітації постраждалих учасників Революції Гідності, учасників антитерористичної операції та осіб, які здійснювали заходи із забезпечення національної безпеки і оборони, відсічі і стримування збройної агресії Російської Федерації у Донецькій та Луганській областях, членів їх сімей та членів сімей загиблих (померлих) таких осіб» URL : https://zakon.rada.gov.ua/laws/show/497-2017-\%D0\%BF\#Text.

23. Розпорядження КМУ від 12 липня 2017 р. № 475-р «Про схвалення Концепції Державної цільової програми з фізичної, медичної, психологічної реабілітації і соціальної та професійної реадаптації учасників антитерористичної операції на період до 2022 року» URL : https://zakon.rada.gov.ua/laws/show/475-2017$\%$ D1\%80\#Text.

24. Постанова КМУ від 27 грудня 2017 р. № 1057 «Про затвердження Порядку проведення психологічної реабілітації учасників антитерористичної операції та постраждалих учасників Революції Гідності» URL : https://zakon.rada.gov.ua/ laws/show/1057-2017-\%D0\%BF\#Text

\section{References}

Vijskovo-medichna doktrina Ukrayini (Proyekt). (2014) O. I. Zatinajko, G. V. Myasnikov. Novosti. Mediciny i farmacii v Ukraine, 19, 3-5.

Steblyuk, V. V., Pronoza-Steblyuk, K. V. (2017). Sistema reabilitaciyi vijskovosluzhbovciv z bojovoyu nejrotravmoyu v Zbrojnih Silah Ukrayini / Med\&Psy Rehab: Materiali mizhnarodnogo kongresu $z$ medichnoyi i psihologichnoyi reabilitaciyi (m. Kiyiv, 30-31 zhovtnya 2017 r.), 84- 86.

Ivanov, A. L. (2003). Psihologicheskie posledstviya uchastiya voennosluzhashih v boevyh dejstviyah $\mathrm{v}$ Chechenskoj respublike i ih medikopsihologo-socialnaya korrekciya $\mathrm{v}$ usloviyah Vsearmejskogo reabilitacionnogo centra. Vestnik psihosocialnoj i korrekcionnoreabilitacionnoj raboty, 4, 32-44.

Ivanov, A. L., Zhumatij, N. V. (2002). Psihologicheskaya reabilitaciya voennosluzhashih, poluchivshih tyazhelye raneniya i uvechya v Chechenskoj Respublike metodom psihoanaliticheskogo konsultirovaniya i psihodramy. Materialy V Vserossijskoj nauchnoprakticheskoj po psihoterapii i klinicheskoj psihologii «Dushevnoe zdorove cheloveka - zdorove nacii», Izd-vo Instituta Psihoterapii.

Machehin, A. E. (2005). V poiskah smysla. Izd. 2-e, pererab. i dop. Moskva : OLMAPRESS. Tourism

A. Linenko, Postgraduate student of the Academy of Labor, Social Relations and ORCID: 0000-0001-9090-1926

\section{Problem issues of legal regulation of psychological rehabilitation of military servants and participants of combat}

The article is devoted to the consideration of the current state of the system of psychological rehabilitation and administrative and legal regulation of combatants who took a direct part in the armed conflict and suffered during the hostilities. The analysis of the legal bases on which the functioning of the domestic system of 
psychological rehabilitation is based is given. Considerable attention is paid to the consideration of the activities of various institutions and organizations for the provision of services for the psychological rehabilitation of combatants.

The professional activity of servicemen is characterized by a high level of psycho-emotional stress, which is associated with the importance and responsibility of solving combat tasks and the presence of a real risk to life. Participation in hostilities can be considered as stressful events of an exceptional nature that cause general distress in almost everyone, due to the negative factors associated with being in a group of people at increased risk of developing asthenic disorders.

Today, the Ukrainian state is undergoing profound domestic political, social and economic changes that have affected all spheres of life and every citizen. One of the main characteristics of these changes is the increase in the frequency and scale of extreme conditions. Extremity permeates the life of large social groups, individual regions and entire states. Fighting in the east of the country, corruption, social instability, political and economic crisis, all these events have not only far-reaching social, material, cultural, medical, but also psychological consequences.

World statistics on natural disasters, catastrophes and hostilities show that the number of cases of neuropsychiatric disorders, depending on the type of extreme situation can be $10-25 \%$ of the total number of people involved in the situation. These psycho-emotional losses require not only the involvement of a large number of specialists to provide assistance to victims, but also significant attention from the state and government agencies in the form of funding for state programs of psychological rehabilitation, and so on.

All this is directly related to the personnel of the Armed Forces and other military formations that become participants in the epicenter of events. In these circumstances, unit commanders must be armed with psychologically sound methods of organizing the activities of personnel, as well as have an education in the legal framework governing the psychological rehabilitation of servicemen. This, of course, will reduce the percentage of psychological losses, increase the efficiency of units in extreme conditions and ensure a rapid recovery of their combat effectiveness.

However, despite the existence in the Ukrainian legislation of a number of legal documents governing the rehabilitation of servicemen during injuries or psychological trauma, the current legislation of Ukraine is not able to fully ensure the proper level of comprehensive rehabilitation of servicemen of the Armed Forces of Ukraine and other military formations. took a direct part in hostilities. This scientific material reveals a number of problematic issues at the legislative level and offers its own vision of resolving urgent needs and inconsistencies in the administrative and legal field.

Keywords: conflict in the East; servicemen; participants in hostilities; psychological rehabilitation; military psychiatry; psycho-prevention; mental health. 